\title{
Adult Nigerian with Untreated Pentalogy of Fallot: A Case Report
}

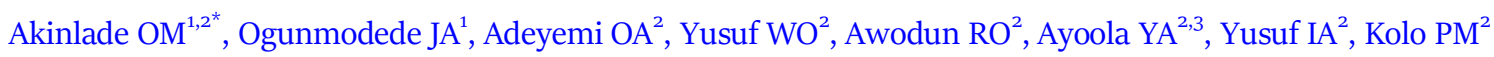

${ }^{1}$ Cardiology unit, Internal Medicine Department, LAUTECH Teaching Hospital, Ogbomoso

${ }^{2}$ Cardiology unit, Internal Medicine Department, University of Ilorin Teaching Hospital, Ilorin, Kwara state

${ }^{3}$ Internal Medicine Department, Gombe Teaching Hospital, Gombe state

Corresponding Author: Akinlade Olawale Mathias

Address: Division of Cardiology, Department of Internal Medicine, LAUTECH teaching Hospital, Ogbomoso, Oyo state, Nigeria; E-mail: Akinlade.o.mathias@gmail.com

Received date: 13 January 2020; Accepted date: 19 February 2020; Published date: 27 February 2020

Citation: Akinlade OM, Ogunmodede JA, Adeyemi OA, Yusuf WO, Awodun RO, Ayoola YA, Yusuf IA, Kolo PM. Adult Nigerian with Untreated Pentalogy of Fallot: A Case Report. Asp Biomed Clin Case Rep. 2020 Feb 27;3(1):62-66.

Copyright (C) 2020 D Akinlade OM, Ogunmodede JA, Adeyemi OA, Yusuf WO, Awodun RO, Ayoola YA, Yusuf IA, Kolo PM. This is an open-access article distributed under the Creative Commons Attribution License, which permits unrestricted use, distribution, and reproduction in any medium provided the original work is properly cited.

\section{Abstract}

Pentalogy of Fallot is a congenital cardiac defect comprising infundibular stenosis of the pulmonary artery, overriding aorta, ventricular septal defect, right ventricular hypertrophy and atrial septal defect. It is one of the most common cyanotic congenital heart defects with detrimental consequences if left untreated. We present the case of a 25-year-old female artisan and stroke survivor who was admitted with episodes of recurrent dizziness. She was diagnosed with the pentalogy of Fallot after echocardiography and awaiting cardiac repair surgery.

\section{Keywords}

Infundibular Stenosis; Pentalogy of Fallot; Ventricular Septal Defects; Overriding Aorta

\section{Introduction}

Pentalogy of Fallot is used to describe the occurrence of the tetralogy of Fallot (TOF) co-existing with atrial septal defects. TOF is described as one of the most common congenital heart disorders comprising: ventricular septal defect (VSD), right ventricular (RV) outflow tract obstruction (RVOTO), over-riding aorta and RV hypertrophy. The mortality rate in untreated patients is still very high. The description of TOF has been ascribed to the work of Stensen (first described it in 1672) and Fallot (first described the clinical and complete pathologic features of the defects). Helen Taussig and Alfred Blalock collaborated to work out the first type of palliation for these infants. Blalock in 1944 operated on an infant with tetralogy of Fallot and created the first Blalock-Taussig shunt between the subclavian artery and the pulmonary artery. Several advances in the diagnosis and management have led to increasing survival outcomes for TOF patients [1].

If left untreated, TOF survivors are at risk of paradoxical emboli leading to stroke, pulmonary embolus, and subacute bacterial endocarditis. The mortality rate is said to be highest in the first year and then remains constant until the second decade. Without surgery, mortality rates gradually increase from $30 \%$ at age 2 years to $50 \%$ by age 6 years. No more than $20 \%$ of patients can be expected to reach the age of 10 years, and less than $5-10 \%$ of patients are alive by the end of their second decade. However, cases of survival of patients into their 8 os have been 
reported. Due to advances in surgical techniques, a $40 \%$ reduction in deaths associated with tetralogy of Fallot was noted from 1979 to 2005.

We report a 25-year-old artisan with untreated TOF in north-central Nigeria.

\section{Case Report}

A 25-year-old artisan with a history of cyanosis and recurrent squatting since childhood presented with complaints of recurrent dizziness of 7 months duration. Dizziness was worse while sitting still or standing, had some episodes of syncopal attack which lasted about 2 minutes, No seizures. She had no history of palpitation, chest pain, dyspnea, orthopnea or paroxysmal nocturnal dyspnea. However, she had a history of progressive easy fatigability on mild exertion. No history of leg swelling. She had a prior history of stroke 11 months earlier with left hemiparesis from which she recovered completely over a period of two months.

General examination revealed an asthenic plethoric young lady, centrally cyanosed with grade 3 digital clubbing. Pulse was regular at a rate of 90 beats per minute. Her blood pressure was 134/80 mmHg. The precordium was hyperactive and the apex was located at $6^{\text {th }}$ left intercostal space, lateral to midclavicular line with palpable systolic thrills over the left sternal border and pulmonary area. A loud pulmonic component of the second heart sound and a pansystolic murmur over the left parasternal area and an ejection systolic murmur over the pulmonary area were heard. The lungs were clear. Abdomen showed no abnormality.

The chest radiograph showed a normal-sized bootshaped heart without pulmonary oligemia. Electrocardiogram revealed sinus rhythm, normal PR interval, right QRS axis deviation, right atrial enlargement, right ventricular hypertrophy. The echocardiography revealed a non-restrictive ventricular septal defect with a large aorta overriding the muscular interventricular septum and atrial septal defect (Ostium Secundum) (Fig-1, Fig-2 and Fig-3). She had eccentric LVH with impaired left ventricular systolic function $(\mathrm{LVEF}=41 \%)$. The right ventricular $\mathrm{EF}$ was $62 \%$, with right ventricular hypertrophy and grade 1 right ventricular diastolic dysfunction. There was no aortic or mitral regurgitation. Peak systolic pulmonary pressure was $52 \mathrm{mmHg}$.

The packed cell volume was $72 \%$ and the blood film showed relative polycythemia. A final diagnosis of TOF with ASD (Pentalogy of Fallot) was made and the patient was placed on beta-blockers and clopidogrel. She has also had serial venesection to reduce her packed cell volume with a slight improvement in

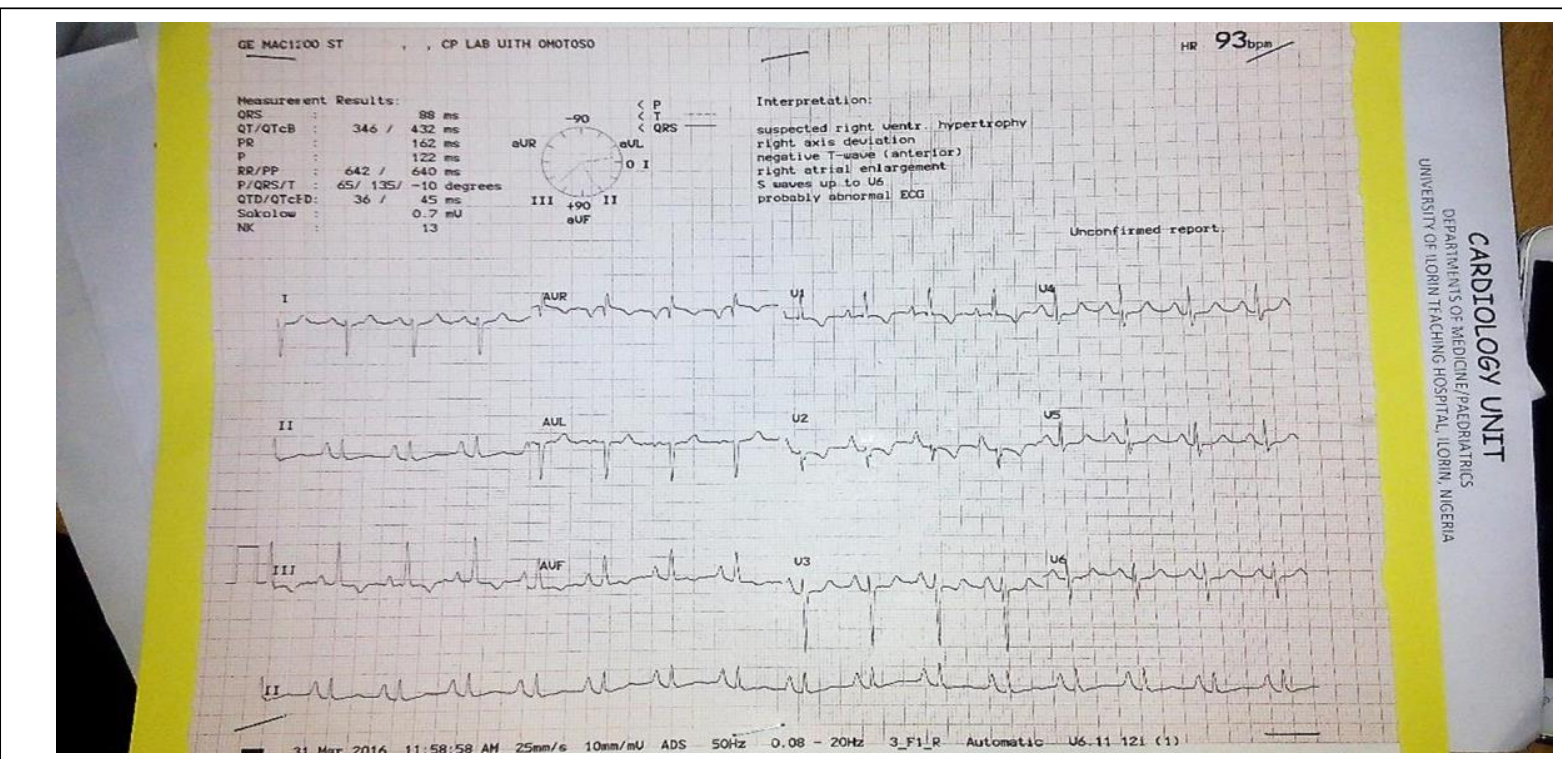

Fig-1: ECG Showing right axis deviation, right atrial enlargement and right ventricular hypertrophy. 
Citation: Akinlade OM, Ogunmodede JA, Adeyemi OA, Yusuf WO, Awodun RO, Ayoola YA, Yusuf IA, Kolo PM. Adult Nigerian with Untreated Pentalogy of Fallot: A Case Report. Asp Biomed Clin Case Rep. 2020 Feb 27;3(1):62-66.

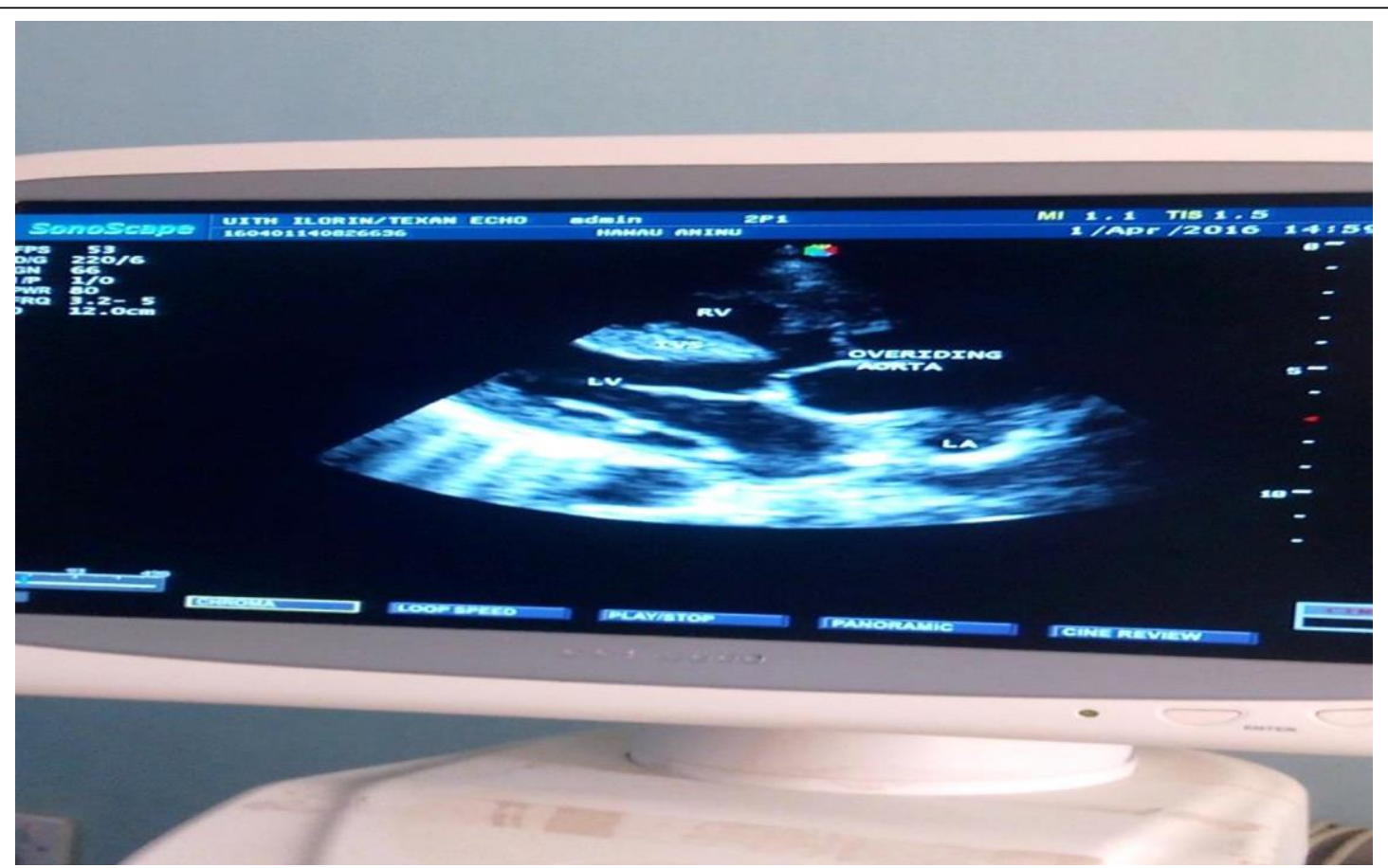

Fig-2: 2-D echo showing the ventricular septal defect and the huge overriding aorta (Parasternal long axis view)

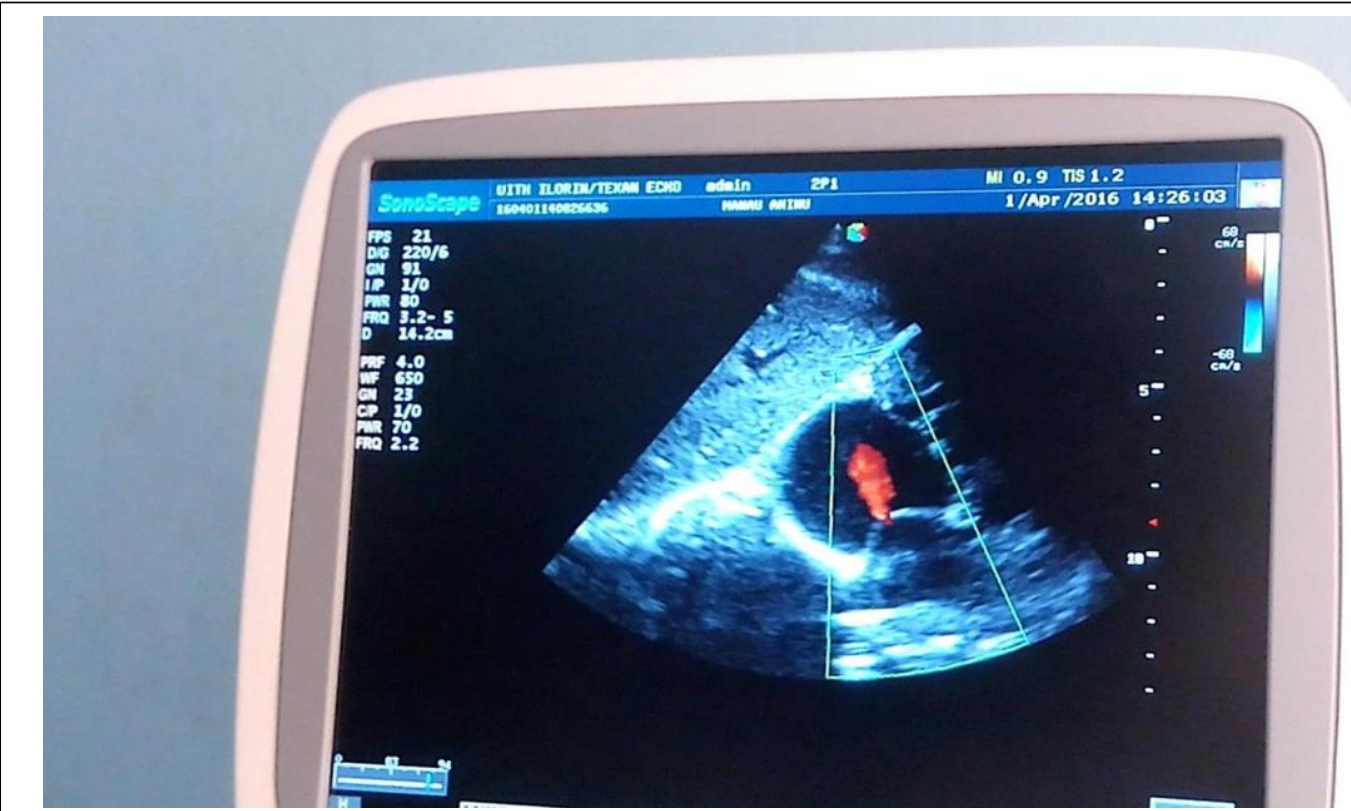

Fig-3: Colour flow study showing flow across atrial septal defect (Subcostal view)

symptoms. She is awaiting total intra-cardiac repair.

\section{Discussion}

Tetralogy of Fallot (TOF) is one of the cyanotic congenital heart disease associated with inadequate blood flow to the lungs for oxygenation (right-to-left shunt). Cyanosis is often first observed shortly after birth, thereby attracting early medical attention. Occasionally, a few children also have an atrial septal defect (ASD), which makes up the pentad of Fallot as seen in this case report. The basic pathology of TOF is due to the underdevelopment of the RV infundibulum, which results in an anterior-leftward malalignment of the infundibular septum [2,3]. This malalignment determines the degree of right ventricular outflow tract obstruction (RVOTO).

Three main reasons have been described to account 
for the longevity in survivors with un-operated TOF. Firstly, a hypoplastic pulmonary artery with the slow development of sub-pulmonary obstruction [4-6]. A second common feature is that of left ventricular hypertrophy; presumably, this acts by delaying of shunting from the right to left ventricle $[7,8]$. Left ventricular hypertrophy (LVH) may be a late development in the natural history of TOF and any beneficial effect may not be seen until adult life. The index case had echocardiographic evidence of $\mathrm{LVH}$ (LVMI =128), this must have accounted for the reduced cyanotic spells she had. The last possible explanation has been extra-cardiac shunts including patent ductus arteriosus [9] reported in one of the survivors who died at age 77 or systemic to pulmonary artery shunting via aortopulmonary collaterals $[7,10]$. The co-existence of ASD in this patient might have equally contributed to her survival to date.

TOF surgeries are usually done around 6-12 months of life, which entail initial shunt procedures, thereafter a corrective surgery is done [2,11-13]. Though Mayo series reported 52 TOF patients, aged $>40$ years who had total correction with a 30-day mortality of $6 \%$ with an improved overall functional class [14]. Though our patient is yet to have surgery, current techniques for total surgical repair greatly improve the hemodynamic functions of the heart of TOF patients. Efforts are being made to ensure that our patients benefit from total intracardiac repair.

For unoperated adults, surgical repair is still recommended because the results are gratifying and the operative risk is comparable to that in pediatric series, provided that no serious coexisting morbidity is present [13-19].

\section{Conclusion}

There is a need for increased suspicion of TOF even among adult patients with a recurrent history of dizziness and or stroke in the young. Surgical correction can improve outcomes among patients. Concerted effort and multidisciplinary collaboration is needed in patient management to identify those that will benefit from corrective surgery to prevent late complications and poor quality of life.

\section{References}

[1] Apitz C, Webb GD, Redington AN. Tetralogy of fallot. The Lancet. 2009 Oct 24;374(9699):1462-71.

[2] Stout KK, Daniels CJ, Aboulhosn JA, Bozkurt B, Broberg CS, Colman JM, Crumb SR, Dearani JA, Fuller S, Gurvitz M, Khairy P. 2018 AHA/ACC guideline for the management of adults with congenital heart disease: a report of the American College of Cardiology/American Heart Association Task Force on Clinical Practice Guidelines. Journal of the American College of Cardiology. 2019 Mar 25;73(12):e81-192.

[3] Karl TR, Stocker C. Tetralogy of Fallot and Its Variants. Pediatr Crit Care Med. 2016 Aug;17(8 Suppl 1):S330-6. [PMID: 27490619]

[4] Tanaka S, Kikuchi N, Hirakawa N, Yamashita K, Kouzuma R, Okazaki M, Tasaki H, Nakashima Y. Prolonged survival in a female with untreated tetralogy of Fallot. J UOEH. 2005 Jun 1;27(2):189-95. [PMID: 15986774]

[5] Yang X, Freeman LJ, Ross C. Unoperated tetralogy of Fallot: case report of a natural survivor who died in his 73rd year; is it ever too late to operate? Postgrad Med J. 2005 Feb;81(952):133-34. [PMID: 15701749]

[6] Meindok H. Longevity in the Tetralogy of Fallot. Thorax. 1964 Jan;19:12-15. [PMID: 14105877]

[7] Thomas SH, Bass P, Pambakian H, Marigold JH. Cyanotic tetralogy of Fallot in a 77 year old man. Postgrad Med J. 1987 May;63(739):361-62. [PMID: 3671268]

[8] Fernicola DJ, Boodhoo VR, Roberts WC. Prolonged survival (74 years) in unoperated tetralogy of Fallot with associated mitral valve prolapse. Am J Cardiol. 1993 Feb 15;71(5):479-83. [PMID: 8430650]

[9] Nottestad SY, Slife DM, Rubal BJ, Moody JM Jr. Tetralogy of Fallot in a 71-year-old patient with new onset hypoxemia. Cathet Cardiovasc Diagn. 1993 Apr;28(4):335-38. [PMID: 7681726]

[10] Subhawong TK, Teytelboym O. Survival to the age of 87 years in a woman with unoperated tetralogy of Fallot. J Radiol Case Rep. 2009;3(8):14-17. [PMID: 22470677]

[11] Van Arsdell GS, Maharaj GS, Tom J, Rao VK, Coles JG, Freedom RM, Williams WG, McCrindle BW. What is the optimal age for repair of tetralogy of Fallot? Circulation. 2000 Nov 7;102(19 Suppl 3):III123-29. [PMID: 11082374]

[12] Hickey EJ, Veldtman G, Bradley TJ, Gengsakul A, 
Manlhiot C, Williams WG, Webb GD, McCrindle BW. Late risk of outcomes for adults with repaired tetralogy of Fallot from an inception cohort spanning four decades. Eur J Cardiothorac Surg. 2009 Jan;35(1):156-64. [PMID: 18848456]

[13] Presbitero P, Demarie D, Aruta E, Villani M, Disumma M, Ottino GM, Orzan F, Fubini A, Spinnler MT, Conte MR. Results of total correction of tetralogy of Fallot performed in adults. Ann Thorac Surg. 1988 Sep;46(3):297-301. [PMID: 2458076]

[14] Attenhofer Jost CH, Connolly HM, Burkhart HM, Scott CG, Dearani JA, Carroll AJ, Tajik AJ. Tetralogy of fallot repair in patients 40 years or older. Mayo Clin Proc. 2010 Dec;85(12):1090-94. [PMID: 21123635]

[15] Huehnergarth KV, Gurvitz M, Stout KK, Otto CM. Repaired tetralogy of Fallot in the adult: monitoring and management. Heart. 2008 Dec;94(12):1663-69.

[PMID: 19011142]

[16] Tsubota H, Nakamura T. Surgical correction of tetralogy of Fallot in a 61-year-old patient. Gen Thorac Cardiovasc Surg. 2012 Mar;6o(3):161-63. [PMID: 22419186]

[17] Hu DC, Seward JB, Puga FJ, Fuster V, Tajik AJ. Total correction of tetralogy of Fallot at age 40 years and older: long-term follow-up. J Am Coll Cardiol. 1985 Jan;5(1):40-44. [PMID: 3964807]

[18] Yamada Y, Ishizu T, Tsuneoka H, Eki Y, Horigome H. A Long-Term Survivor with Tetralogy of Fallot Treated Only with the Classical Blalock-Taussig Shunt. Case Reports Cardiol. 2018:1-4.

[19] Sousa P, Santos W, Marques N, Cordeiro P, Ferrinha R, Pereira S, Almeida A, Jesus I. A 72-yearold woman with an uncorrected tetralogy of Fallot presenting with possible pulmonary endocarditis: a case report. J Med Case Rep. 2013 Jun 2;7:150. [PMID: 23725101] 